\title{
Spontaneous large anterior chest wall haematoma causing haemorrhagic shock during enoxaparin therapy
}

\author{
Pawina Subedi, ${ }^{1}$ Masood Pasha Syed 0 , ${ }^{1}$ Tanvi Shah, ${ }^{1}$ Ahmad Daniyal Siddiqui ${ }^{2}$
}

${ }^{1}$ Internal Medicine, Saint Vincent Hospital, Worcester, Massachusetts, USA ${ }^{2}$ Hematologist/Oncologist, Saint Vincent Hospital, Worcester, Massachusetts, USA

Correspondence to Dr Masood Pasha Syed; dr.syedmasoodpasha@gmail. com

Accepted 8 May 2020

\section{DESCRIPTION}

A 79-year-old male with a history of gastrooesophageal reflux disease, asthma and alcohol use disorder was sent to the emergency room for elevated heart rate detected at his primary care physician's office. He was asymptomatic. Vitals revealed a pulse rate of 110 beats $/ \mathrm{min}$. Physical examination was insignificant. A complete blood count revealed haemoglobin $15.3 \mathrm{~g} / \mathrm{L}$, haematocrit 44.7, white cell count $6.5 \times 10^{9} / \mathrm{L}$, platelet count of $195 \times 10^{9} / \mathrm{L}$. Basic metabolic panel revealed sodium 140 , potassium 4, chloride 107, anion gap 12, Blood Urea Nitrogen (BUN) $18 \mathrm{mg} / \mathrm{dl}$, creatinine $1.18 \mathrm{mg} /$ dl. Liver function test showed total bilirubin 0.9, direct bilirubin 0.3, Aspartate aminotransferase (AST) 31, Alanine transaminase (ALT) 33, Alkaline phosphatase (ALP) 63. Prothrombin time (PT) 10.9, partial prothrombin time (PTT) 30.4, international normalized ratio (INR) 1 . He was started on a diltiazem drip for supraventricular tachycardia later established as atrial flutter as per the electrocardiogram (EKG). He was admitted to the floor and his heart rate was well-controlled with metoprolol, and apixaban was started. He became increasingly drowsy presumably secondary to alcohol withdrawal and anticoagulation was switched from apixaban to subcutaneous enoxaparin as he could not tolerate oral medications. Cardioversion was deferred due to active alcohol withdrawal.

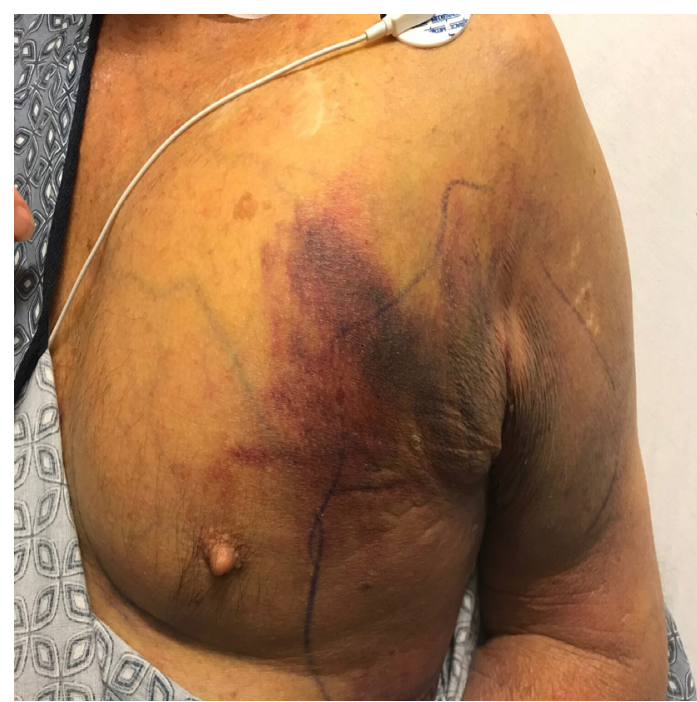

Figure 1 Anterior-view of chest wall haematoma during enoxaparin use.

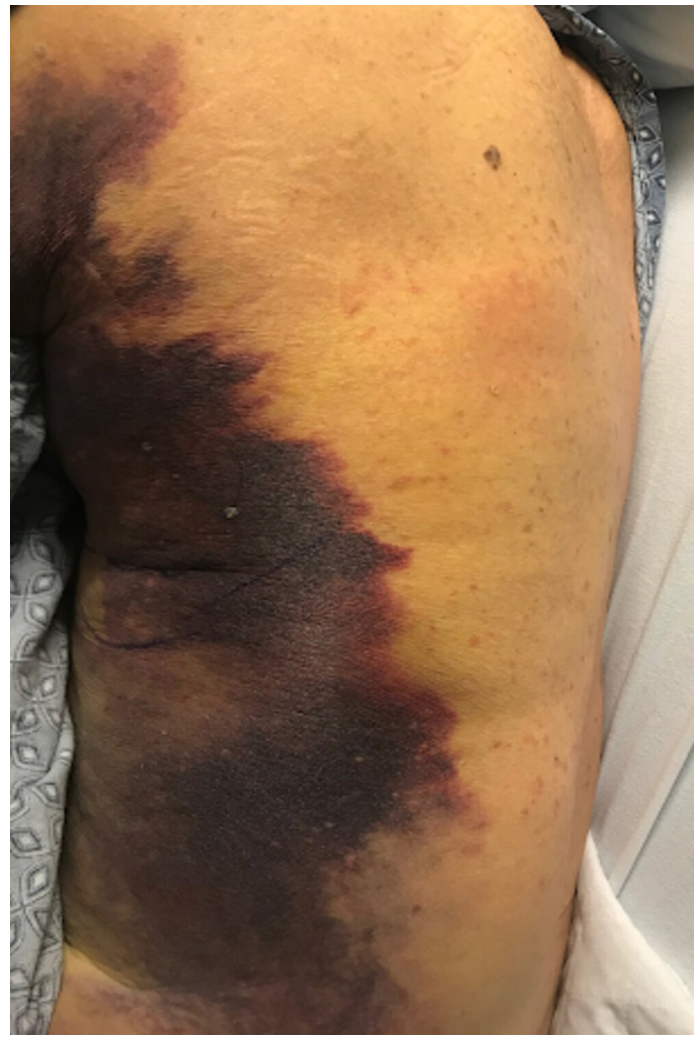

Figure 2 Lateral-view chest wall haematoma during enoxaparin use.

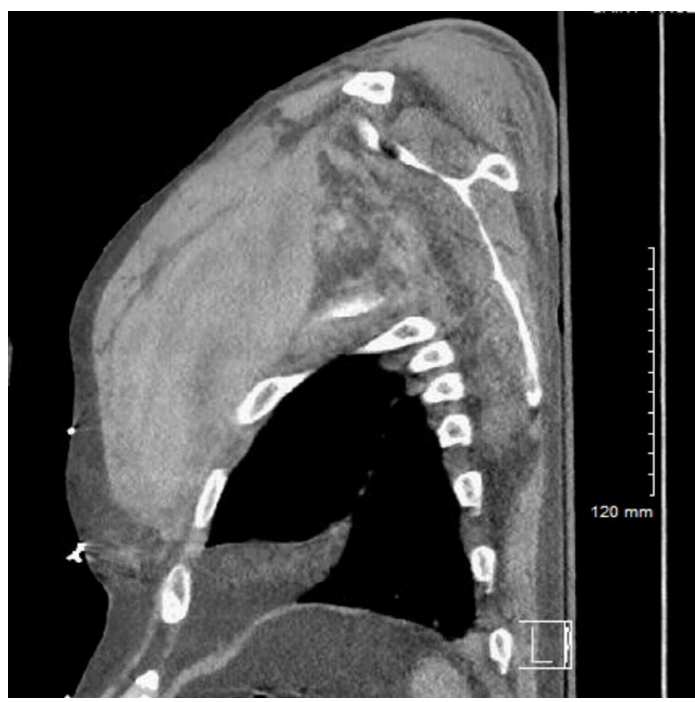

Figure 3 Lateral view of CT imaging of chest wall haematoma. 


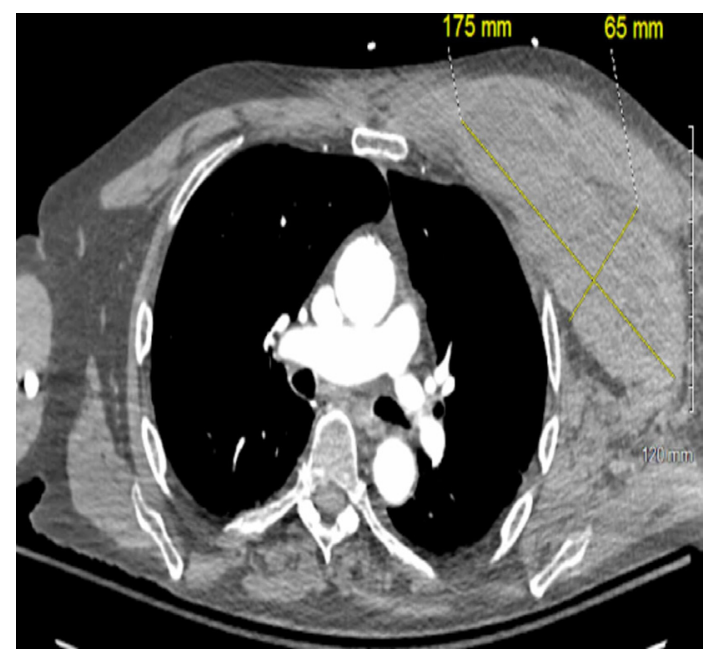

Figure 4 Coronal view of CT imaging of chest wall haematoma.

On day 3, a large anterior chest wall swelling was noted associated with hypotension of 86/58 $\mathrm{mm} \mathrm{Hg}$ (figures 1 and 2). Enoxaparin was stopped, fluid resuscitation initiated and the patient was transferred to the intensive care unit for further management of presumed haemorrhagic shock. Haemoglobin dropped from 9.1 to 7.1 and haematocrit from 27.3 to 20.7. CT angiogram of chest revealed a large $17.5 \times 15.9 \times 6.5 \mathrm{~cm}$ subpectoral haematoma extending from the clavicle superiorly to the anterolateral chest wall inferiorly (figures 3-5).

Two units of packed red blood cells (RBCs) were administered and surgical consultation was pursued. Conservative management was done with external pressure applied via thoracoabdominal binder. He remained haemodynamically stable but his mental status did not improve. Lab values showed elevation in $\mathrm{BUN} /$ creatinine from $18 / 1.1$ at admission to $81 / 6.08$, respectively. Haemodialysis was initiated for oliguric acute kidney injury due to haemorrhagic shock-induced acute tubular necrosis

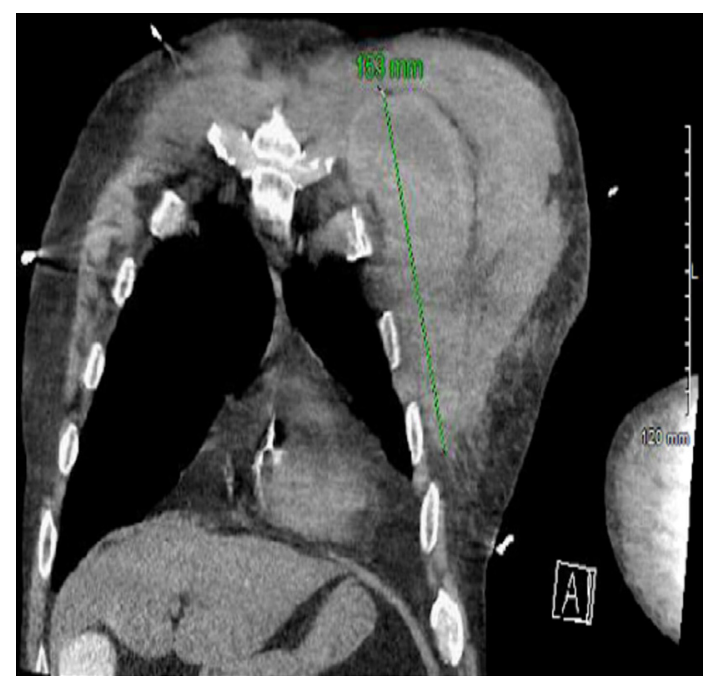

Figure 5 Axial view of CT imaging of chest wall haematoma. and contrast-induced nephropathy (CIN). His mental status improved temporarily but there was an increase in the size of the chest wall haematoma. Stat aortography with visceral angiography showed an active bleed and extravasation of contrast from the left lateral thoracic artery which was embolised by interventional radiology (IR). He remained haemodynamically stable and another haemodialysis session was done for concern of additional insult from CIN. He was then transitioned to the medical floor and discharged home after 3 days.

Chest wall haematomas are often caused by trauma, although anticoagulation use and tumours are implicated in a smaller fraction of non-traumatic cases. ${ }^{1}$ Our patient did not have any traumatic insult and had a spontaneous anterior chest wall haematoma while on enoxaparin for new-onset atrial flutter. His creatinine clearance $(\mathrm{CrCl})$ which was normal during admission subsequently decreased to $<30 \mathrm{~mL} / \mathrm{min}$. This is an important number to remember as enoxaparin clearance is decreased by $27 \%$ in patients with $\mathrm{CrCl}<30 \mathrm{~mL} / \mathrm{min}^{2}$ Enoxaparin was immediately stopped in our patient on the same day of having developed the noticeable swelling. However, given his renal dysfunction and advanced age, enoxaparin may have stayed longer in his system further complicating his haematoma. A timely surgical/IR intervention was crucial in his management. Our literature search showed enoxaparin induced spontaneous chest wall haematomas to be rare. ${ }^{3}$ Caution needs to be exercised while using enoxaparin in the elderly.

\section{Learning points}

Anterior chest wall haematomas are uncommon without preceding trauma and are a rare reported complication of anticoagulation use with enoxaparin.

- Caution needs to be exercised when prescribing enoxaparin to elderly individuals with decreased creatinine clearance $(<30 \mathrm{~mL} / \mathrm{min})$. Studies suggest a higher incidence of bleeding with enoxaparin in this population. ${ }^{4}$

Contributors PS: concept, design, literature search, writing manuscript. MPS: concept, design, writing manuscript, supervision, critical review. TS: literature search, writing manuscript, critical review. ADS: concept, supervision, writing manuscript.

Funding The authors have not declared a specific grant for this research from any funding agency in the public, commercial or not-for-profit sectors.

Competing interests None declared.

Patient consent for publication Obtained.

Provenance and peer review Not commissioned; externally peer reviewed.

ORCID iD

Masood Pasha Syed http://orcid.org/0000-0002-3252-9094

\section{REFERENCES}

1 Sato N, Sekiguchi $H$, Hirose $Y$, et al. Delayed chest wall hematoma caused by progressive displacement of rib fractures after blunt trauma. Trauma Case Rep 2016:4:1-4.

2 Shaikh SA, Regal RE. Dosing of enoxaparin in renal impairment. P T 2017;42:245-9.

3 Dohan A, Darnige L, Sapoval M, et al. Spontaneous soft tissue hematomas. Diagn Interv Imaging 2015:96:789-96.

4 Salemis NS, Oikonomakis I, Lagoudianakis E, et al. Enoxaparin-induced spontaneous massive retroperitoneal hematoma with fatal outcome. Am J Emerg Med 2014:32:1559.e1-1559.e3. 
Copyright 2020 BMJ Publishing Group. All rights reserved. For permission to reuse any of this content visit https://www.bmj.com/company/products-services/rights-and-licensing/permissions/

BMJ Case Report Fellows may re-use this article for personal use and teaching without any further permission.

Become a Fellow of BMJ Case Reports today and you can:

- Submit as many cases as you like

- Enjoy fast sympathetic peer review and rapid publication of accepted articles

Access all the published articles

Re-use any of the published material for personal use and teaching without further permission

Customer Service

If you have any further queries about your subscription, please contact our customer services team on +44 (0) 2071111105 or via email at support@bmj.com.

Visit casereports.bmj.com for more articles like this and to become a Fellow 